\title{
A new lower Cambrian shelly fossil biostratigraphy for South Australia
}

\section{Reply}

Marissa J. Betts, John R. Paterson, James B. Jago, Sarah M. Jacquet, Christian B.

\section{Skovsted, Timothy P. Topper and Glenn A. Brock}

Kruse et al. (2016) have highlighted aspects of the new shelly fossil biozonation of Betts et al. (2016) that conflict with prior biostratigraphic assessments of early Cambrian successions from South Australia. The chief issue is that our new data suggest that these successions are older than previously understood.

\section{Archaeocyaths}

Kruse et al. (2016) suggest that because the K. rostrata Zone and the pre-trilobitic portion of the M. etheridgei Zone coincide with the W. wilkawillinensis, S. tenuis and J. tardus archaeocyath zones (Zhuravlev and Gravestock, 1994), they should correlate with the Atdabanian in the Siberian scheme (Series 2, Stage 3), not the Terreneuvian, Stage 2, as presented in Betts et al. (2016). However, global archaeocyath correlation is problematic as they are highly endemic (Peng et al., 2012). For example, of the 37 genera recorded from Wilkawillina Gorge and Mt. Scott Range, only eight occur in the Altai-Sayan region in Siberia (Gravestock, 1984, p. 10). Shelly fossil correlation is also often based on genera, but intense study has revealed that robust global correlation can be made with key shelly fossil species (Betts et al., in review). Additionally, the new shelly fossil scheme employs a wide array of taxa, which conforms to Gravestock's (1984, p. 8) suggestion that correlation should be based on "diverse fossil suites...rather than by comparative morphological evolution of a single group." 
Kruse et al. (2016) note that the S. favus beds of Zhuravlev and Gravestock (1994) have a wider distribution than that described in Betts et al. (2016), and suggest that the assemblage indicates a Botoman age (upper Stage 3 - Stage 4).We have taken a more cautious approach in correlating our new biozones with regional stages (e.g. Siberia) and the currently undefined Cambrian Stages 2, 3 and 4 of the global scale, and we stand by our comments regarding the unreliability of archaeocyath genera as correlation tools. To illustrate, Kruse et al. (2016) note that the S. favus beds in East Gondwana represent an assemblage that contains genera (e.g., Stillicidocyathus and Pycnoidocyathus) that are restricted to the Botoman in Siberia. However, , Yang et al. (2016) report the occurrence of Stillicidocyathus and Pycnoidocyathus from the earliest and latest Canglangpuan, respectively, of the Yangtze Platform in South China. Yang et al. (2016, fig. 7) correlate these intervals with the late Atdabanian and early Toyonian in Siberia, respectively. It is also important to note that, in the context of South Australian biozones, the $S$. favus beds are considered by Paterson et al. (2007) to be older than the Pararaia janeae trilobite Zone based on co-occurring shelly assemblages (contra Zhuravlev and Gravestock 1994, fig. 4; Yang et al. 2016, fig. 7; Kruse et al. 2016, fig. 1).

\section{Shelly Fossils}

Kruse et al. (2016) reject our comment (Betts et al. 2016, p. 188) regarding works such as Bengtson et al. (1990) and Gravestock et al. (2001) as predating “extensive modern systematic treatments of key shelly fossil taxa from South Australia”. These monographs are extremely important, but they do predate modern understanding of the palaeobiology, functional morphology and phylogeny of many shelly fossil taxa. Later studies demonstrate that taxa of biostratigraphic importance, such as Askepasma, Dailyatia, Eccentrotheca, Kulparina, Micrina, and Paterimitra, have more complex and varied morphologies than previously realised (for a list of relevant references, see Skovsted 2015 and Betts et al. 2016). 
Lists of bradoriid, brachiopod and lobopodian genera known from Cambrian Stages 3 and 4 in other parts of the world are simply not compelling evidence for direct correlation with all three of the new shelly zones of Betts et al. (2016). Firstly, this approach implies that it is not possible for some of these genera to extend lower in the stratigraphy elsewhere in the world, regardless of discoveries of new species in East Gondwana. Some of the genera listed by Kruse et al. (2016) are problematic in that they are either "wastebasket" (and thus longranging) taxa (e.g., Eoobolus) or exhibit highly variable morphologies (e.g., Microdictyon; see Topper et al., 2011).

\section{Molluscs}

Jacquet and Brock (2015) show that identification and stratigraphic occurrence of molluscs is strongly influenced by taphonomy, hence their use in biostratigraphic studies must be treated with caution. As discussed in Betts et al. (2016, p. 189), the informal mollusc zones of Gravestock et al. (2001) lack clearly defined boundaries and their application is inconsistent. Utilising molluscs for biostratigraphic work hinges on accurate identification, but this is often difficult or impossible when shell ornament is not preserved. In early Cambrian molluscs, external ornament is rarely preserved and identification is based on the gross shape of the steinkern. When external ornament is preserved, differences that merit definition of a range of species (and possibly even genera) are often apparent (Skovsted, 2006). Thus, it is likely that previous identifications of micromollusc taxa from steinkern material (such as all those listed by Kruse et al., 2016) have seriously underestimated the taxonomic diversity of the group, thus limiting their current biostratigraphic utility.

\section{Trilobites}

Trilobites provide the most robust means of correlating lower Cambrian biozones between South Australia and South China, especially those that comprise the Qiongzhusian Stage of the Yangtze Platform (Paterson and Brock, 2007; Steiner et al., 2007). In both regions, there 
is a distinct stratigraphic sequence of taxa that commences with the oldest species and its eponymous zone, Abadiella (or Parabadiella) huoi.`

Immediately overlying the $P$. huoi Zone in Australia and China, the respective Pararaia tatei and Wutingaspis-Eoredlichia zones are correlated based on the occurrence of Eoredlichia shensiensis. Steiner et al. (2001) subdivided the Wutingaspis-Eoredlichia Zone into a lower Tsunyidiscus subzone and upper Yunnanocephalus subzone. The co-occurrence of Wutingaspis, Eoredlichia and Yunnanocephalus in the latter subzone permits possible correlation with the Pararaia bunyerooensis Zone in South Australia.

These correlations suggest that the $P$. huoi, $P$. tatei and $P$. bunyerooensis zones in South Australia are equivalent to the entire Qiongzhusian Stage in South China (Paterson and Brock, 2007; Steiner et al. 2007), but there is some uncertainty about how this regional stage fits into the global Cambrian timescale. Recent studies place the base of the Qiongzhusian either at (e.g., Zhang et al. 2008, fig. 1; Yang et al. 2016, fig. 7) or slightly above (e.g., Kouchinsky et al. 2012, fig. 3; Landing et al. 2013, fig. 4; Yun et al. 2016, fig. 11) the base of Stage 3.

In the context of our new shelly fossil biozonation for South Australia, the P. huoi Zone equates to the upper part of the $M$. etheridgei Zone, and the base of the P. tatei Zone approximates the base of the D. odyssei Zone. Hence, the pre-trilobitic portion of the $M$. etheridgei Zone is Meishucunian in age, and is situated immediately below or above the boundary between Cambrian Stages 2 and 3, depending on the placement of the Meishucunian-Qiongzhusian boundary against the global chronostratigraphic scheme. This age determination for the pre-trilobitic part of the $M$. etheridgei Zone is supported by the occurrence of Micrina xiaotanensis from the basal Yu'anshan Formation at Xiaotan ( $\mathrm{Li}$ and Xiao, 2004), where its limited stratigraphic range occurs below the FAD of trilobites and is associated with the eponyms of the S. flabelliformis-T. zhangwentangi Assemblage Zone. 
Notably, this late Meishucunian SSF assemblage also contains Lapworthella rete; we thank Kruse et al. (2016) for correctly pointing out that L. rete does not overlap with $M$. xiaotanensis at the Xiaotan section. Thus, pre-trilobitic occurrences of Micrina and Lapworthella in the S. flabelliformis-T. zhangwentangi Zone of China and the M. etheridgei Zone of Australia conform to the overlying trilobite biozonation in both regions.

\section{Conclusion}

As we have previously noted (Betts et al., 2016, p. 191), precise correlation of our newly established shelly fossil biozonation outside of East Gondwana is problematic. This is due to uncertainties of correlating at the genus level for any group (given the high levels of species endemism), and even problems that arise from trying to correlate at the species level (e.g. mollusc steinkerns). Hence, we have provided a tentative correlation only with South China, given the close faunal ties with South Australia (Betts et al., 2016). Forthcoming work however, demonstrates global application of early Cambrian shelly fauna to high resolution biostratigraphy and correlation (Betts et al., in review).

There is no reason or evidence to suggest that the early Cambrian scheme of Siberia should be the temporal yard-stick by which all other chronostratigraphic schemes are measured. Evidence for pronounced time breaks in key sections has required reassessment of biostratigraphy and correlation in Siberia (Knoll et al., 1995). Kruse et al. (2016) rigidly adhere to an outdated Sibero-centric view of Cambrian chronostratigraphy, which is obstructing progress toward a fully resolved global Cambrian timescale. The correlation chart provided by Kruse et al. (2016, fig. 1) is a classic example of early Cambrian global correlation based on data that have not been updated in 15 years.

Global correlation by Betts et al. (2016; in review; Brock et al. in Gehling et al. 2016) is based on multiple temporal proxies - shelly fossil biostratigraphy, carbon isotope 
chemostratigraphy and new, highly accurate CA ID-TIMS radiometric dates that together build a tightly calibrated chronostratigraphic scheme for the early Cambrian of South Australia.

\section{References}

Bengtson S., Conway Morris, S., Cooper, B.J., Jell, P.A. and Runnegar, B.N., 1990. Early Cambrian fossils from South Australia. Memoir of the Association of Australasian Palaeontologist 9, 1-364. Betts, M. J., Paterson, J. R., Jago, J. B., Jacquet, S. M., Skovsted, C. B., Topper, T. P. and Brock, G. A. 2016. A new lower Cambrian shelly fossil biostratigraphy for South Australia. Gondwana Research 36, 176-208.Betts, M. J., Paterson, J. R., Jago, J. B., Jacquet, S. M., Skovsted, C. B., Topper, T. P. and Brock, G. A. In review. Shelly fossils from the Dailyatia odyssei biozone (Cambrian Series 2, Stages 34), Arrowie Basin, South Australia. Gondwana Research.

Gravestock, D. 1984. Archaeocyatha from lower parts of the Lower Cambrian carbonate sequence in South Australia. Memoir of the Association of Australasian Palaeontologists 2, 139.

Gravestock, D. I., Alexander, E. M., Demidenko, Y. E., Esakova, N. B., Holmer, L. E., Jago, J. B., Lin, T.R., Melnikova, N., Parkhaev, P. Y., Rozanov, A. Y., Ushatinskaya, G. T., Zang, W.L., Zhegallo, E. A. and Zhuravlev, A. Y. 2001. The Cambrian biostratigraphy of the Stansbury Basin, South Australia. Transactions of the Palaeontological Institute of the Russian Academy of Sciences 282, 1-341.

Jacquet, S. M. and Brock, G. A. 2015. Lower Cambrian helcionelloid macromolluscs from South Australia. Gondwana Research 36,333-358.

Knoll, A. H., Kaufman, A. J., Semikhatov, M. A., Grotzinger, J. P. and Adams, W. 1995. Sizing up the sub-Tommotian unconformity in Siberia. Geology 23, 1139-1143. 
Kouchinsky, A., Bengtson, S., Runnegar, B., Skovsted, C., Steiner, M. and Vendrasco, M., 2012. Chronology of early Cambrian biomineralization. Geological Magazine 149, 221251.

Kruse, P. D., Zhuravlev, A., Parkhaev, P. and Zhu, M. 2016. Comment: A new lower Cambrian shelly fossil biostratigraphy for South Australia. Gondwana Research.

Li, G. and Xiao, S., 2004. Tannuolina and Micrina (Tannuolinidae) from the Lower Cambrian of eastern Yunnan, south China, and their scleritome reconstruction. Journal of Paleontology 78, 900-913.

Landing, E., Geyer, G., Brasier, M.D. and Bowring, S.A., 2013. Cambrian Evolutionary Radiation: Context, correlation, and chronostratigraphy-Overcoming deficiencies of the first appearance datum (FAD) concept. Earth-Science Reviews 123, 133-172.

Paterson, J.R. and Brock, G.A., 2007. Early Cambrian trilobites from Angorichina, Flinders Ranges, South Australia, with a new assemblage from the Pararaia bunyerooensis Zone. Journal of Paleontology 81, 116-142.

Paterson, J.R., Skovsted, C.B., Brock, G.A. and Jago, J.B., 2007a. An Early Cambrian faunule from the Koolywurtie Limestone Member (Parara Limestone), Yorke Peninsula, South Australia and its biostratigraphic significance. Memoir of the Association of Australasian Palaeontologists 34, 131-146.

Peng, S., Babcock, L. and Cooper, R. 2012. The Cambrian Period. The geologic time scale, 2, 437-488.

Skovsted, C.B. 2006. Small shelly fossils from the basal Emigrant Formation (Cambrian, uppermost Dyeran Stage) of Split Mountain, Nevada. Canadian Journal of Earth Sciences 43: 487-496. 
Skovsted, C., Betts, M., Topper, T. and Brock, G. 2015. The early Cambrian tommotiid genus Dailyatia from South Australia. Memoir of the Association of Australasian Palaeontologists 48, 1-117.

Steiner, M., Li, G., Qian, Y., Zhu, M. and Erdtmann, B.-D., 2007. Neoproterozoic to Early Cambrian small shelly fossil assemblages and a revised biostratigraphic correlation of the Yangtze Platform (China). Palaeogeography, Palaeoclimatology, Palaeoecology 254, 6799.

Steiner, M., Zhu, M.-Y., Weber, B. and Geyer, G., 2001.The Lower Cambrian of eastern Yunnan: Trilobite-based biostratigraphy and related faunas. Acta Palaeontologica Sinica 40 (supplement), 63-79.

Topper, T. P., Brock, G. A., Skovsted, C. B. and Paterson, J. R. 2011. Microdictyon plates from the lower Cambrian Ajax Limestone of South Australia: Implications for species taxonomy and diversity. Alcheringa 35, 427-443.

Yang, A.-H., Zhu, M.-Y., Zhuravlev, A.Yu., Yuan, K., Zhang, J.-M. and Chen, Y.-Q., 2016. Archaeocyathan zonation of the Yangtze Platform: Implications for regional and global correlation of lower Cambrian stages. Geological Magazine 153, 388-409.

Yun, H., Zhang, X.-L., Li, L.-Y., Zhang, M. and Liu, W., 2016. Skeletal fossils and microfacies analysis of the lowermost Cambrian in the southwestern margin of the North China Platform. Journal of Asian Earth Sciences 129, 54-66.

Zhang, X.-L., Liu, W. and Zhao, Y.-L., 2008. Cambrian Burgess Shale-type Lagerstätten in South China: Distribution and significance. Gondwana Research 14, 255-262.

Zhuravlev, A. Y. and Gravestock, D. I. 1994. Archaeocyaths from Yorke Peninsula, South Australia and archaeocyathan Early Cambrian zonation. Alcheringa 18, 1-54. 